\title{
BATS OF COASTAL SOUTHWESTERN TASMANIA
}

\author{
by Martin Schulz and Kris Kristensen
}

(with two tables and one text-figure)

SChulz, M. \& KRISTensen, K., 1996 (30:vi): Bats of coastal southwestern Tasmania. Pap. Proc. R. Soc. Tasm. 130(1): 1-5.

https://doi.org/10.26749/rstpp.130.1.1 ISSN 0080-4703. Faculty of Resource Science and Management, Southern Cross University, PO Box 157, Lismore, NSW, Australia 2480 (MS); Trinity Inlet Management Program, PO Box 6896, Cairns, Qld, Australia 4870 (KK). A survey of bats was undertaken in coastal southwestern Tasmania from Bond Bay north to Pilot Bay at Macquarie Harbour entrance. Survey sites were located within wet scrub and buttongrass moor vegetation communities, predominantly along watercourses or on ecotones with beaches or marsupial lawns. Of the eight species of bats so far known from Tasmania, only Falsistrellus tasmaniensis was not recorded in the present survey. A total of 53 individuals were captured in 111 mistnethours from 22 survey sites sampled, including five species not previously recorded from southwestern TasmaniaNyctophilus timoriensis, Chalinolobusgouldii, C. morio, Vespadelus darlingtoni and V vulturnus. The most widespread and frequently trapped species was N. geojfroyi. Species captured infrequently were $V$ regulus and $N$. timoriensis (two sites) and $V$ vulturnus (one site). Key Words: bats, mistnet, southwestern Tasmania.

\section{INTRODUCTION}

Little survey workhasbeen conducted on bats in southwestern Tasmania, with the majority of survey effort confined to the vicinity of Melaleuca airstrip adjacent to Melaleuca Inlet (e.g. Schulz \& Menkhorst cited in Taylor et al. 1987, Taylor \& Comfort 1993, Department of Parks, Wildlife \& Heritage records). This paper reports the results of a survey of bats of coastal southwestern Tasmania, from Bond Bay north to Macquarie Heads, which was conducted during February and early March 1993. Prior to the present survey, only three of the eight recognised bat species occurring in Tasmania had been recorded in the southwestern region - the lesser longeared bat Nyctophilus geoffroyi, King River bat Vespadelus regulus and the Tasmanian pipistrelle Falsistrellus tasmaniensis (Taylor et al. 1987, Rounsevell et al. 1991, Watts 1993); the last was not found in the present study.

\section{METHODS}

The survey of bats or coastal southwestern Tasmania was undertaken as part of a general fauna survey conducted while traversing the coast on foot from Bond Bay north to Macquarie Heads between 9 February and 11 March 1993 (Schulz \& Kristensen 1993a, b, Kristensen and Schulz 1994).

Twenty-two survey sites were sampled (fig. 1), from Bond Bay in the south to Pilot Bay at Macquarie Harbour entrance in the north. All sites were sampled on only a single night. Survey sites were either deliberately selected as being suitable for trapping bats, due to the presence of suspected "flyways" along creeks (Taylor \& O’Neill 1985), or were set at sites where we were forced to camp for the night.

Survey sites occurred within two principal vegetation communities which, following the classification of Kirkpatrick \& Dickinson (1984), were wet scrub (91\%), and buttongrass moor (9\%). The majority of sites were located over watercourses up to $150 \mathrm{~m}$ from the shoreline within wet scrub $(50 \%)$ or in ecotones with beaches $(23 \%)$ or marsupial lawns (9\%) immediately adjacent to the shoreline (table 1). All sites were located at altitudes of less than $10 \mathrm{~m}$ above sea level.
Three techniques were employed to survey the bat fauna of coastal southwestern Tasmania.

(1) Monofilament mistnetting. At all 22 sites, between one and four monofilament mistnets of three lengths, $5.5 \mathrm{~m}, 12.9 \mathrm{~m}$ and $18.5 \mathrm{~m}$, were set as single nets angled across watercourses or gaps in dense vegetation. In more open areas, double and triple nets were set in Y-shaped and Z-shaped patterns, as described in Helman \& Churchill (1986). Nets were set for a minimum period of one hour after dusk. Taylor $\&$ O'Neill (1988) found that bats in all habitats sampled in Tasmania

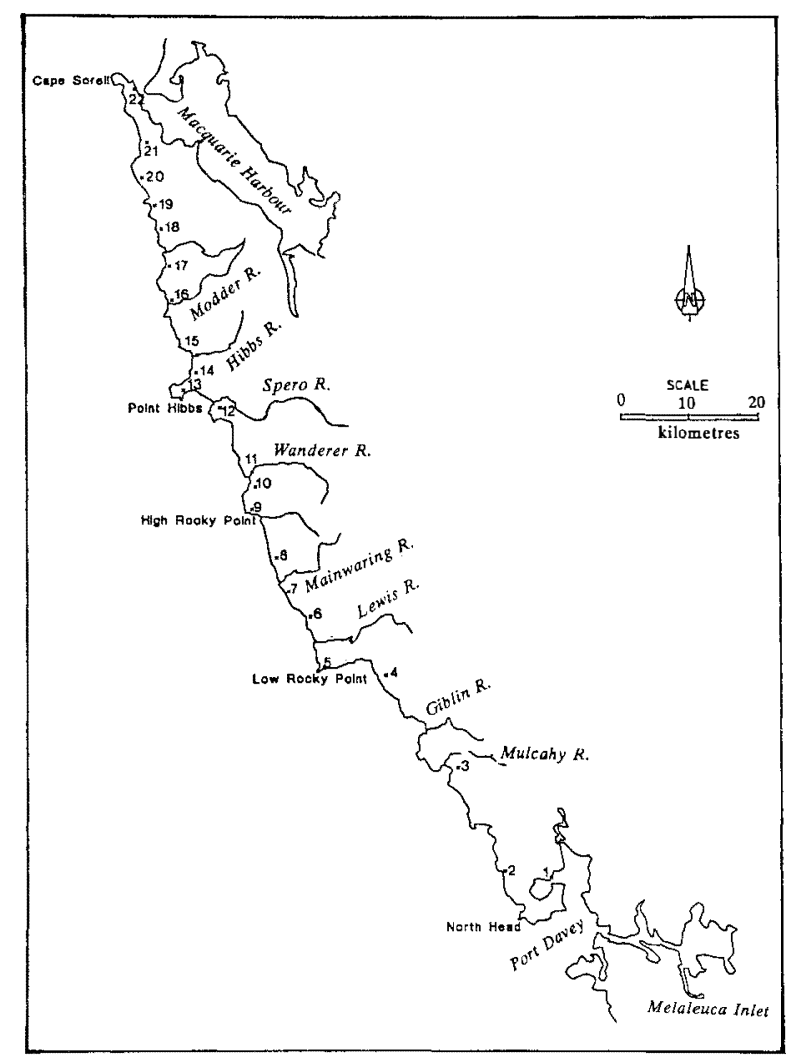

FIG. 1 - Survey sites for bat survey of coastal southwestern Tasmania. Numbers correspond with listing in table 1. 
TABLE 1

Survey sites, dates of field work, broad vegetation types, trapping effort and numbers of species of bats recorded

\begin{tabular}{|c|c|c|c|c|c|c|}
\hline $\begin{array}{l}\text { Site } \\
\text { no. }\end{array}$ & Locality & Grid ref. & Date & Habitat* & $\begin{array}{l}\text { Trap } \\
\text { effort }^{\dagger}\end{array}$ & $\begin{array}{l}\text { Species } \\
\text { recorded }\end{array}$ \\
\hline 1 & Bond Bay beach & $43^{\circ} 15^{\prime} \mathrm{S}, 145^{\circ} 54^{\prime} \mathrm{E}$ & 9.2 .93 & Wet scrub/beach & 4.5 & 1 \\
\hline 2 & Paradise Lagoon & $43^{\circ} 15^{\prime} \mathrm{S}, 145^{\circ} 49^{\prime} \mathrm{E}$ & 10.2 .93 & Wet scrub/creek & 6.0 & 0 \\
\hline 3 & Alec Rivulet, Mulcahy Bay & $43^{\circ} 07^{\prime} \mathrm{S}, 145^{\circ} 43^{\prime} \mathrm{E}$ & 12.2 .93 & Wet scrub/creek & 1.0 & 0 \\
\hline 4 & Unmarrah Creek mouth & $43^{\circ} 01^{\prime} \mathrm{S}, 145^{\circ} 38^{\prime} \mathrm{E}$ & 14.2 .93 & Wet scrub/marsupial lawn & 2.25 & 1 \\
\hline 5 & Low Rocky Point & $42^{\circ} 59^{\prime} \mathrm{S}, 145^{\circ} 29^{\prime} \mathrm{E}$ & 16.2 .93 & Buttongrass moor & 1.25 & 0 \\
\hline 6 & Sassy Creek mouth & $42^{\circ} 55^{\prime} \mathrm{S}, 145^{\circ} 29^{\prime} \mathrm{E}$ & 17.2 .93 & Wet scrub/creek & 12.0 & 4 \\
\hline 7 & Stinky Creek mouth & $42^{\circ} 53^{\prime} \mathrm{S}, 145^{\circ} 27^{\prime} \mathrm{E}$ & 18.2 .93 & Wet scrub/marsupial lawn & 10.0 & 4 \\
\hline 8 & Reuben Creek & $42^{\circ} 49^{\prime} S, 145^{\circ} 25^{\prime} E$ & 19.2 .93 & Wet scrub/creek & 4.0 & 1 \\
\hline 9 & Minder Cove & $42^{\circ} 46^{\prime} \mathrm{S}, 145^{\circ} 23^{\prime} \mathrm{E}$ & 20.2 .93 & Wet scrub/beach & 4.0 & 1 \\
\hline 10 & South of Hartwell Cove & $42^{\circ} 44^{\prime} \mathrm{S}, 145^{\circ} 23^{\prime} \mathrm{E}$ & 21.2 .93 & Wet scrub/beach & 2.0 & 1 \\
\hline 11 & Wanderer River mouth & $42^{\circ} 43^{\prime} \mathrm{S}, 145^{\circ} 23^{\prime} \mathrm{E}$ & 22.2 .93 & Wet scrub/beach & 4.0 & 1 \\
\hline 12 & Spero River mouth & $42^{\circ} 38^{\prime} \mathrm{S}, 145^{\circ} 20^{\prime} \mathrm{E}$ & 27.2 .93 & Wet scrub/river & 9.0 & 2 \\
\hline 13 & Whitehorses Beach & $42^{\circ} 37^{\prime} \mathrm{S}, 145^{\circ} 18^{\prime} \mathrm{E}$ & 28.2 .93 & Buttongrass moor/beach & 4.0 & 1 \\
\hline 14 & Evans Creek mouth & $42^{\circ} 36^{\prime} \mathrm{S}, 145^{\circ} 18^{\prime} \mathrm{E}$ & 1.3 .93 & Wet scrub/creek & 4.0 & 3 \\
\hline 15 & Hibbs Lagoon mouth & $42^{\circ} 34^{\prime} \mathrm{S}, 145^{\circ} 18^{\prime} \mathrm{E}$ & 2.3 .93 & Wet scrub/creek & 6.0 & 0 \\
\hline 16 & Modder River mouth & $42^{\circ} 30^{\prime} \mathrm{S}, 145^{\circ} 15^{\prime} \mathrm{E}$ & 3.3 .93 & Wet scrub/river & 5.0 & 2 \\
\hline 17 & Birthday Creek mouth & $42^{\circ} 27^{\prime} \mathrm{S}, 145^{\circ} 15^{\prime} \mathrm{E}$ & 4.3 .93 & Wet scrub/creek & 3.0 & 2 \\
\hline 18 & North of Birthday Bay & $42^{\circ} 25^{\prime} \mathrm{S}, 145^{\circ} 14^{\prime} \mathrm{E}$ & 5.3 .93 & Wet scrub/creek & 7.5 & 0 \\
\hline 19 & South of Gotge Point & $42^{\circ} 22^{\prime} \mathrm{S}, 145^{\circ} 13^{\prime} \mathrm{E}$ & 6.3 .93 & Wet scrub & 5.0 & 0 \\
\hline 20 & South of Sloop Point & $42^{\circ} 20^{\prime} \mathrm{S}, 145^{\circ} 12^{\prime} \mathrm{E}$ & 7.3 .93 & Wet scrub & 7.5 & 0 \\
\hline 21 & South of The Grandfathers & $42^{\circ} 16^{\prime} \mathrm{S}, 145^{\circ} 13^{\prime} \mathrm{E}$ & 8.3 .93 & Wet scrub/creek & 4.0 & 1 \\
\hline 22 & Pilot Bay & $42^{\circ} 12^{\prime} \mathrm{S}, 145^{\circ} 12^{\prime} \mathrm{E}$ & 10.3 .93 & Wet scrub & 5.0 & 3 \\
\hline
\end{tabular}

* Broad vegetation types (after Kirkpatrick \& Dickinson 1984)/position of mistnet (over watercourses or marsupial lawn/beach ecotones).

$\dagger$ Trap effort measured in mistnet hours.

concentrated their foraging activities to an initial period of three hours after dark. In order to obtain a measure of relarive net success for each species, the number of mistnet hours sampled at a particular site represented the number of nets set, irrespective of net length for the sample period. Mistnets were constantly monitored to retrieve bats before they chewed their way through the net and escaped.

(2) Triplining. This technique was only used at a single site in buttongrass moor at Low Rocky Point. Fine nylon fishing line $(0.25 \mathrm{~mm}$ diameter) was stretched tightly about $20-30 \mathrm{~mm}$ above a still water surface. Bats coming in to drink hit such lines, and some are flipped into the water, forcing them to swim to the bank where they can be caught (Helman \& Churchill 1986). As with mistnets, triplining requires a person to be constantly monitoring the lines in order to stop bats from reaching the bank and escaping.

(3) Search of sea caves. All sea caves, overhangs along watercourses and crevices in rock faces encountered were searched for roosting bats.

Mistnetting was conducted on 22 nights of the 32-day survey. Climatic conditions ranged from calm weather to wind speeds of less than 20 knots, no rain to showers and squalls, and no moon to full moon. On the remaining nine nights, survey work was not conducted, due to adverse climatic conditions with wind speeds of over 20 knots and/or constant rain, or to forced camp sites in situations where it was not feasible to erect nets, because of the nature of the terrain, the lateness of arrival or the physical condition of the authors.

\section{RESULTS}

Seven of the eight species of bats known from Tasmania were recorded in this survey. In a total of 111 mistnet hours at 22 survey sites, 53 individuals (all species combined) or $0.48 \mathrm{bats} / \mathrm{mistnet}$ hour were captured. The greatest number of species recorded from a single site was four species (two occasions) and no bats were recorded from seven sites (table 1). Trapping results for bats recorded during the survey are given in table 2. No bats were caught using the triplining technique.

Nyctophilus geoffroyi was the most commonly trapped (20 individuals) and widespread species (nine sites), with a capture rate of 1.8 individuals/ten mistnet hours. Other species recorded in more than five survey sites were Chalinolobus morio (nine individuals trapped at seven sites) and $C$. gouldii (11 individuals trapped at four sices). One species, Vespadelus vulturnus, was trapped as a single individual from one site. Two species were recorded from only two survey sites, $N$. timoriensis and $V$. regulus.

All seven species were recorded from wet scrub, while only one, $N$. geoffroyi, was trapped in buttongrass moor. Six species (C. gouldii, C. morio, $N$. geoffroyi, $N$. timoriensis, $V$. regulus and $V$. darlingtoni) were captured in miscnets set over watercourses fringed by wet scrub. Four species ( $C$. gouldii, $C$. morio, $N$. geoffroyi and $V$. darlingtoni) were trapped on the ecotone of wet scrub and shorcline, and four (C. morio, $N$. geoffroyi, $N$. timoriensis and $V$. darlingtoni) on the ecotone of wet scrub and marsupial lawns immediately adjacent to the shoreline. $V$. vulturnus was only captured in a mistnet angled across a four-wheel drive track behind Pilot Bay at Macquarie Harbour entrance. 
No bats were located in sea caves or overhangs along watercourses, although several sea caves which could potentially provide suitable roost sites were located between the Mainwaring River and Endeavour Bay. The only roosting bat encountered was a single $N$. geoffroyi located $4 \mathrm{~m}$ above the ground in a tangle of bark and sticks accumulated in the fork of a Eucalyptus nitida, north of Christmas Cove ( $42^{\circ} 42^{\prime} \mathrm{S}$, $145^{\circ} 23^{\prime} \mathrm{E}$ ).

\section{DISCUSSION}

The seven species recorded in the survey area represent $88 \%$ of the known bat species of Tasmania. This compares with $50 \%$ found by Taylor et al. (1985) in the Upper Henty River region of western Tasmania and 12\% found by Green (1979) in the Sumac Forest and Dempster Plains in northwestern Tasmania. All species of bats recorded from the Upper Henty River region and from the Sumac Forest and Dempster Plains were found in the present study area.

Prior to the present survey, only three species of bats had been recorded from southwestern Tasmania (Taylor et al. 1987, Rounsevell et al. 1991, Taylor \& Comfort 1993). The most frequently recorded species was $N$. geoffroyi. This bat was found roosting on occasions in the bushwalkers' huts at Melaleuca (M. Schulz, pers. obs.) and for periods of time in the Willson's house a Melaleuca (P. \& B. Willson, pers. comm.). It was also captured in mistnets set around D. King's garden at Melaleuca (M. Schulz \& K. Menkhorst, unpubl. rec.). No individuals of this species were caught in harp traps or recorded by an ultrasonic bat detector at Melaleuca and Claytons by Taylor \& Comfort (1993). Away from Melaleuca, $N$. geoffroyi has been caught in monofilament mistnets at Schooner Cove, Cox Bight, Louisa Bay and Louisa River (M. Schulz \& K. Menkhorst unpubl. rec., Taylor et al. 1987).

Two other bat species previously recorded from southwestern Tasmania appear to be restricted in distribution within this region. $V$. regulus, captured only once in the present survey, had been recorded by M. Schulz and K. Menkhorst (cited in Taylor et al. 1987) and Taylor \& Comfort (1993) at Melaleuca. (The latter authors did not trap this species at the sice but obcained a bat recording that "most closely resembled" it.)

The Tasmanian pipistrelle Falsistrellus tasmaniensis, previously recorded from the New Harbour area on the south coast (Taylor et al. 1987, Rounsevell et al. 1991), was not located this time, possibly because all trapping was confined to wet scrub and buttongrass moor vegetation communities rather than taller forest communities.

The present study, together with previous records, has shown that all eight species of bats recorded for Tasmania occur in southwestern Tasmania. Rounsevell et al. (1991) suggested that $C$. morio, $N$. geoffroyi $V$. darlingtoni and $V$. regulus are probably distributed throughout most of the state while $C$. gouldit, $F$. tasmaniensis, $N$. timoriensis and $V$ vulturnus may be limited within the perhumid cold climatic zone (after Gentilli 1972). The present survey showed $C$ gouldii to be widely distributed in this climatic zone and $N$. timoriensis to be patchily distributed; no information was available for $F$. tasmaniensis. V. vulturnus, on the other hand, was only recorded in the humid warm zone (Gentilli 1972) at Macquarie Harbour entrance and may possibly be absent from the perhumid climatic zone of southwestern Tasmania.

Five of the species now recorded (C. gouldii, C. morio, $N$. timoriensis, $V$. darlingtoni and $V$. vulturnus) had not been located previously in southwestern Tasmania (Taylor et al. 1987, Rounsevell et al. 1991). The first two were widespread, being recorded at four and seven sites respectively. $V$. darlingtoni was recorded from three sites, $N$. timoriensis from two sites and V. vulturnus from a single site (table 2). The location of five additional bat species was attributed to the survey effort undertaken in this study and sampling of areas not previously surveyed. In the most comprehensive survey previously undertaken in the region (Taylor \& Comfort 1993) at Melaleuca, a total survey effort of five harp trap nights, two nights of mistnetting and four nights of 45-minute sampling, using a Anabat II (Titley Electronics) bat detector, yielded no bat captures and only two bat passes recorded with the detector. The present survey sampled 22 sites with a total of 111 mistnet hours, averaging 5.1 mistner hours/site. This effort resulted in recording bats (one species or more) at $68 \%$ of sites, with three or more species recorded in $18 \%$ of sites sampled.

Bat species diversity is generally considered to be low in western Tasmania (Taylor \& O'Neill 1985, Taylor et al. 1987, Taylor \& Comfort 1993). Taylor et al. (1987) attributed this to the cold climatic conditions and high rainfall of the region in comparison with eastern Tasmania. The present survey has demonstrated that bat species diversity overall in coastal southwestern Tasmania is comparable

TABLE 2

Summary of trapping results in the survey of bats in coastal southwestern Tasmania

\begin{tabular}{lcccc}
\hline Species & $\begin{array}{c}\text { Total } \\
\text { trapped }\end{array}$ & $\begin{array}{c}\text { Vegetation community* } \\
\text { Wet scrub }\end{array}$ & $\begin{array}{c}\text { Buttongrass moor } \\
\text { recorded }^{\dagger}\end{array}$ \\
\hline Nyctophilus geoffroyi & 20 & + & + & $7,8,10,12,13,14,17,21,22$ \\
Chalinolobus gouldii & 11 & + & - & $6,11,14,16$ \\
C. morio & 9 & + & - & $1,4,7,12,14,16,22$ \\
Vespadelus regulus & 5 & + & - & 6,17 \\
N. timoriensis & 4 & + & - & 6,7 \\
V. darlingtoni & 3 & + & - & $6,7,9$ \\
V. vulturnus & 1 & + & 22 \\
\hline
\end{tabular}

* After Kirkpatrick \&. Dickinson (1984).

$\dagger$ Site numbers used are those identified in table 1. 
with that of eastern Tasmania. In foresced sites in eastern Tasmania, trapping records indicate that it is not uncommon for seven or eight species to occur sympatrically (Taylor $e t$ al. 1987). During the present survey, in a single night of mistnetting at each of four sites, three or four species were recorded. Since the use of mistnets is generally considered to be less effective than harp traps (e.g. Richards 1992), and all net sites during the present survey were located in scrub rather than forested situations, a survey of coastal forests in western Tasmania deploying harp traps and ultrasonic bat detectors could reveal a similar bat species diversity, with the possible absence of $V$. vulturnus, to that in many forested sicuations in eastern Tasmania.

The density of bats present in coastal southwestern Tasmania appears to be lower than in eastern Tasmania, although no data was collected to quantify this. Taylor $\&$ Comfort (1993), using an Anabat II detector, demonstrated a marked difference in bat passes, with 80 times greater number of passes in dry forest in eastern Tasmania compared with around Melaleuca Inlet. However, the bat fauna present at Melaleuca appears depauperate and is unlikely to be representative of southwestern Tasmania as a whole. For example, in over 50 monofilament mistnet hours in late 1992 and early 1993, M. Schulz and K. Menkhorst (unpubl. rec.) recorded only $12 N$. geoffroyi and three $V$. regulus. These results are low compared with many sices sampled in a single night during the present survey. At some locations during the survey, such as south of Hartwell Cove and at the Wanderer River mouth, large numbers of bats were observed foraging over the shoreline and adjacent vegetation. Both these sites were close to rainforest and E. nitida wet forest vegetation communities (Kirkpatrick \& Dickinson 1984). Fishermen reported on some summer nights having large numbers of bats flying around boats anchored close inshore at The Pophole, south of Low Rocky Point (C. Wessing, pers. comm.) where E. nitida wet forest immediately flanks the shoreline in this area.

In a total of 544 bats trapped at nine sites in eastern, western and northwestern Tasmania, Taylor et al. (1987) found the following relative proportions of each species: $V$. regulus $35 \%, C$. morio $20 \%, V$. darlingtoni $12 \%, V$. vulturnus $11 \%, N$. geoffroyi $10 \%, F$. tasmaniensis $7 \%, N$. timoriensis $3 \%$ and $C$. gouldii $2 \%$. In the present survey, the relative proportions of trapped species was: $N$. geoffroyi $38 \%, C$. gouldii $21 \%, C$ morio $17 \%, V$. regulus $9 \%, N$. timoriensis $8 \%, V$. darlingtoni $5 \%$ and $V$. vulturnus $2 \%$. Thus, of the three most frequently captured species in southwestern Tasmania, only one ( $C$. morio) rated in the top three bat species trapped by Taylor et al. (1987). The species recorded least frequently by Taylor et al. (1987), C. gouldii, was the second most commonly trapped species in the present study, while species of the genus Vespadelus, comprising only $16 \%$ of all bats caught, accounted for $58 \%$ in the earlier survey. The differing results may be due to a combination of factors, including different vegetation communities and climatic zones sampled, and differences in trapping techniques (e.g. harp traps [Taylor] v. mistnets [present study]).

The remoteness of the southwestern region and surveying on foot grearly restricted techniques available for sampling the bat fauna. The harp trap (Tuttle 1974, Tidemano \& Woodside 1978), which has been widely and successfully used for capturing all Tasmanian bat species (Taylor et al. 1987, O'Neill \& Taylor 1989), is a large, bulky, heavy piece of equipment, totally unsuitable for carrying through the dense trackless vegetation of southwestern Tasmania. Deployed around melaleuca Inlet, such traps have met with only limired success (Department of Parks, Wildlife \& Heritage records, Taylor \& Comfort 1993). For example, Taylor \& Comfort (1993) trapped no bats in five harp traps nights around D. King's garden and mine workings in this area. In the present survey, these traps were not used, due to the dense nature of the vegetation, the necessity of restricting the weight of backpacks for the 32-day walking survey and the difficulty of carrying such traps across ten rivers where all gear had to be floated. Techniques were limited to mistnetting and triplining. As a result, the survey depended on mistnetting as the prime technique, although not carrying mistnet poles but using "bush poles" of reasonably straight, dead branches, driftwood or dead sapling trunks.

Mistnets have a number of drawbacks and consequently are rarely used as the prime survey method in general fauna surveys where remoteness and vehicle access is not a problem (e.g. Richards 1992, Schulz \& de Oliviera, pers. obs.) Some of the drawbacks of mistnets are listed below.

(1) Mistnets bias against species which are slow flying and have sufficient manoeuvrability to avoid them, or species that have high-frequency echolocation calls that enable them to detect knots and shelf strings in mistnets. These problems were partially overcome by deploying ultrafine monofilament mistnets, less likely to be detected. To maximise the possibility of catching slow-flying manoeuvrable species, such as Nyctophilus, nets were set in puzzle formations or slanted across openings, in an effort to trick the bats.

(2) Mistnets have to be constantly monitored, and it is difficult to survey a number of sires concurrently. In the present survey, mistnets were always erected within easy walking distance from the campsite. This was both to conserve torch batteries, of which we had only a limited supply, and to allow for regular checking of nets while undertaking other duties such as erecting the camp, cooking dinner, repairing equipment and writing-up the day's notes. No attempt was made to sample more than one site per night, for the reasons outlined previously and because the authors had been walking all day with heavy backpacks, often over difficult terrain (Kristensen \& Schulz 1994) and frequently did not have the energy to constant monitor distant sites.

(3) Monofilament mistnets are generally regarded as expendable survey items, due to their fragile nature (e.g. Helman \& Churchill 1986). In the present survey, the ners used became progressively more full of holes, due to wind catching the nets and wrapping them around vegetation, and on occasions flocks of ducks flew into and sometimes through the nets, resulting in gaping holes. By the end of the survey, most ners were more holes than useful net and were difficult to deploy successfully.

Despite the limitations of using mistnets as the primary bat survey technique, the results demonstrated that monofilament mistnets are a useful bat survey tool, where terrain and remoteness restrict other techniques.

Another widely used bat survey tool, the ultrasonic bat detector, was not used in the present survey. Detection of ultrasonic calls requires the careful use of delicate electronic equipment (de Oliviera et al. 1994) not resistant to water. It was considered impractical to carry a bat detector, cassette recorder, cassette tapes and a large supply of batteries, and the equipment might well have failed in wet weather or during river crossings and/or accidental submersion of backpacks in the sea. The only localities in coastal south- 
western Tasmania where ultrasonic bat detectors have been used are at Melaleuca and Clayrons on the southern shore of Barhurst Harbour (Taylor \& Comfort 1993). However, in future surveys of western Tasmania, it is recommended that a waterproofed bat detector also be deployed as, at a number of sites, bats were observed lying around but none were caught in the nets.

The absence of bats in sea caves scattered along the coast, particularly in the High Rocky Point area, was not a surprise. No cave-dwelling bats have been reported in Tasmania (Taylor et al. 1987, Rounsevell et al. 1991, Watts 1993). Hall (1981) indicated that cave-dwelling species are generally less numerous in mainland Australia than forest roosting species and decrease in numbers with increasing latitude.

\section{ACKNOWLEDGEMENTS}

This survey was made possible by research grants from the Department of Parks, Wildlife and Heritage and Australian Geographic. Thanks to Sally Bryant for organising the bat trapping and airdrop permits; to Alan and Erika Johnson of the yacht Camira of Hobart for transport from Melaleuca Inlet to Bond Bay; to Peter and Barbara Willson for their hospitality, home brew and organising the lift to Bond Bay; to Paul Helleman, District Ranger, Strahan, for organising a boat to pick us up at Macquarie Heads; to "George" and "Jerry" for saving us from coffee withdrawal and advising the Department of Parks, Wildlife and Heritage of a pick-up time at Macquarie Heads; to Kelvin Barrett for picking us up at Macquarie Heads and transporting us to Strahan; to fishermen off the FY Birralee for saving us a swim across the Mainwaring River; to Melva Truchanas for providing a base in Hobart; and to Par Avion for assisting in the packing and deposicing of the airdrops at Big Beach and Whitehorses Beach. Thanks also to Professor P. Baverstock, Dr L. Hall and Dr R. Taylor for commenting on a previous draft of the manuscript.

\section{REFERENCES}

De Oliviera, M.C., Corben, C. \& Hogan. L.D., 1994: Ultrasonic detection of micro-bats in southeastern Queensland. Department of Primary Industries Forest Service, Fauna Conservation and Ecology Section, Brisbane. Internal report.

GENTILLI, J., 1972: AUSTRALIAN CLIMATIC PATTERNS. Nelson, Melbourne.
GREEN, R.H., 1979: A survey of the vertebrate fauna of the Sumac Forest and the Dempster Plains, north-west Tasmania. Rec. Queen Vic. Mus. 65:1-9.

HALL,L.S., 1981: The biogeography of Australian bats. In Keast, K.(Ed.): ECOLOGICAL BIOGEOGRAPHY OF AUSTRALIA. Dr W. Junk, The Hague: 1557- 1583.

Helman, P. \& ChurChill, S., 1986: Bat capture techniques and their use in surveys. Macroderma 2: 32-53.

KiRKPATRICK, J.B. \& DiCKINSON, K.J.M., 1984: TASMANIAN VEGETATIONMAP. Tasmanian Forestry Commission, Hobart.

Kristensen, K. \& SChulz, M. 1994: The wild, wild west. Austr. Geogr. 35: 25-26.

O'Neill, M.G. \& Taylor, R.J., 1989: Feeding ecology of Tasmanian bat assemblages. Aust. J. Ecol. 14: 19-31.

Richards, C.C., 1992: Fauna survey. Wingham Management Area, Port Macquarie region. For. Resour. Ser. 22, For. Commn NSW, Sydney.

Rounsevell, D.E., Taylor, R.J. \& Hocking, G.J., 1991: Distribution records of native terrestrial mammals in Tasmania. Wildl. Res, 18: 699-717.

SCHUlz, M. \& KRISTENSEN, K., 1993a: A survey of the shorebirds of western Tasmania. Part Two. North Head. Port Davey entrance to Macquarie Heads. The Stilt 23: 26-29.

SChulz, M. \& KRISTEnSEN, K, 1993b: Coastal fauna survey of western Tasmania, with comments on management. Internal Report. World Heritage Area, Dept Parks, Wildl. Heritage, Hobart.

TAYLOR, R.J. \& COMFORT, M.D., 1993: Small terrestrial mammals and bats of Melaleuca and Claytons. southwestern Tasmania. Pap. Proc. R. Soc. Tasm. 127: 33-37.

TAYLOR, R.J. \& O'NeILl, M.G., 1985: Composition of the bat (Chiroptera: Vespertilionidae) communities in Tasmanian forests. Aust. Mamm. 9: 125-130.

TAYLOR, R.J. \& O’NeILl, M.G., 1988: Summer activity patterns of insectivorous bats and their prey in Tasmania. Aust. Wildl. Res. 15: 533-539.

Taylor, R.J., O'Neili, M.G. \& Reardon, T., 1987: Tasmanian bats: Identification, distribution, and natural history. Pap. Proc. R. Soc. Tasm. 121:109-119.

Taylor, R.J., Bryant, S.L., Pemberton, D. \& Norton, T.W., 1985: Mammals of the Upper Henty Region, western Tasmania. Pap. Proc. R. Soc. Tasm. 119: 7-14.

Tidemann, C.R. \& Woodside. D.P., 1978: A collapsible battrap and a comparison of results obtained with the trap and mist-nets. Aust. Wildl. Res. 5: 355-362.

TUTTLE, M.D., 1974: An improved trap for bats. J. Mammal. 55: 474-477.

WATTS, D., 1993: TASMANIAN MAMMALS, A FIELD GUIDE. Rev, ed. Focal Printing, Hobart.

(accepted 20 June 1995) 